\title{
Language Abilities of Monolingual Turkish Speaking Children Who Stutter Türkçe Konuşan Tek Dilli Kekemeliği Olan Çocukların Dil Yetileri
}

\author{
${ }^{1}$ Ayşe Aydın Uysal, ${ }^{2}$ Saniye Tülin Fidan \\ ${ }^{1}$ Kocaeli Üniversitesi Eğitim Fakültesi, Özel Eğitim Bölümü,Kocaeli,Türkiye \\ ${ }^{2}$ Eskişehir Osmangazi Üniversitesi Tıp Fakültesi, Çocuk Psikiyatrisi Anabilim Dalı,Eskişehir,Türkiye
}

\begin{abstract}
The aim of this study was to examine differences in language abilities between children who stutter and their age and gender matched peers with typical development. In this cross-sectional study, subjects were two groups of 25 children $(\mathrm{N}=50)$ between the ages of 3;5 and 7;11 (years; months) who do (CWS) (mean age $=6 ; 5$ ) and do not stutter $($ CWNS) (mean age $=6 ; 4)$. We administered the Turkish version of Test of Early Language Development (TELD-3) to evaluate receptive and expressive language abilities of children participated in this study. The main findings of the study were that expressive subtest and composite scores of CWS on TELD-3-T were significantly lower than CWNS while the difference between groups was not significant on TELD-3-T receptive subtest score. Expressive language scores and total language scores of CWS are below their peers.
\end{abstract}

Keywords: stuttering, receptive language, expressive language, Turkish

Uysal Aydın A. Fidan Saniye T. (2017). Language Abilities of Monolingual Turkish Speaking Children who Stutter Değerlendirmesi, Osmangazi Tup Dergisi 2017, 39(31-36): Doi:

Özet: Bu çalışmanın amacı kekemeliği olan ve yaş ve cinsiyetleri eşleştirilmiş tipik gelişim gösteren çocukların dil performanslarının karşılaştırılmasıdır. Kekemeliği olan 3;5 ve 7;11 yaşları arasındaki 25 çocuğa $($ ort. $=6 ; 5)$ ve yaş ve cinsiyetleri eşleştirilmiş tipik gelişim gösteren akranlarına (ort. $=6 ; 4)$ Türkçe Erken Dil Gelişim Testi (TEDİL) uygulanarak alıcı ve ifade edici dil becerileri değerlendirilmiştir. Kekemeliği olan çocukların TEDİL testinin ifade edici dil ve toplam dil puanı ortalamaları tipik gelişim gösteren çocuklardan anlamlı düzeyde düşük bulunurken, alıcı dil alt testinde iki grup arasında anlamlı düzeyde bir farklılık bulunmamıştır. Kekemeliği olan çocukların ifade edici dil ve toplam dil performansları yaşıtlarının gerisindedir.

Anahtar Kelimeler: kekemelik, alıcı dil, ifade edici dil, Türkçe

Uysal Aydın A. Fidan Saniye T. (2017). Türkçe Konuşan Tek Dilli Kekemelĭgi Olan Çocukların Dil Yetileri, Osmangazi Journal of Medicine 2017, 39 (31-36): Doi: 


\section{Introduction}

Stuttering is a communication disorder characterised by disruptions in the normal flow of speech accompanied by physical tension or struggle. Although the exact cause of stuttering is unknown, experts agree that it is probably caused by a combination of factors. Language is thought to be one of these factors playing an important role in the onset, development and maintenance of stuttering $(1,2,3)$.

The relation between stuttering and language has been of interest for many years. Several authors have proposed that language factors may play a role in the onset, development and maintenance of stuttering $(4,2,5,6,7,8,9)$. Although the question of a possible link between language and developmental stuttering has a long history, the literature regarding this possible link is mixed. Several studies noted that CWS as a group are more likely than CWNS to have language difficulties $(10,1,2,3)$. The reason for the link between language and stuttering has been given several explanations such as the onset of stuttering coinciding with the rapid development of syntactic, morphologic and lexical development (11) or stuttering often increasing with children's attempts to produce longer and more complex utterances $(12,13)$. However, results from other studies have been contradictory, pointing to normal or advanced language development in CWS $(14,4,15)$. Research based on data from longitudinal studies, such as Illinois Stuttering Research Program have revealed that advanced levels of expressive language skills can even be a risk factor for dysfluency by putting excessive demand on a still maturing speech motor system (16). Many divergent results in these studies concerning stuttering and language can be explained by methodological differences and shortcomings. Different measures of language are used to assess a range of language skills including phonology, morphosyntax, lexical knowledge, semantics and pragmatics. While some researchers used measures from natural language samples like mean length of utterance (MLU) evaluating only expressive language skills, some others used Peabody Picture Vocabulary TestRevised assessing only receptive vocabulary. Limited number of studies provide a broader assessment of language abilities in a group of children with stuttering. CWS in these studies were compared to an age and gender matched group of children with typical development and their language abilities were measured using both standardized language tests and measures of spontaneous speech (17).

Although stuttering occurs in all languages, stuttering patterns can be different across languages due to language specific idiosyncrasies. Cross-linguistic studies are needed to find out general stuttering laws and differences between languages. In Turkey, research concerning the language abilities of children with stuttering is limited to loci of stuttering in spontaneous speech $(18,19)$ and to our knowledge there is no study exploring the language abilities of CWS comprehensively with standardized tests. So the aim of this preliminary study is to investigate the differences in expressive and receptive language abilities between CWS and their age and gender matched peers with typical development.

\section{Materials and Methods}

\section{Participants}

25 children with stuttering were recruited from speech and language therapy clinics in Eskişehir Research and Training Center for Speech and Language Pathology. The typically developed children in the control group $(\mathrm{N}=25)$ were all candidates recruited from a local primary school in Eskisehir. The researchers gave information about the aim of the study and informed consents of parents or caregivers of all children participated in this study were received. The CWS were matched by gender and age ( \pm 4 months) to the CWNS. All subjects were native speakers of Turkish with no history of neurological, hearing, or intellectual problems per parent report and examiner observation. Children with stuttering had no concominant speech or language disorder and none of the children from either group received any therapy for language, articulation or stuttering before.

Turkish Test of Early Language Development (TELD-3-T)

Turkish Test of Early Language Development (TELD-3-T) is a standardized and normed language test which was translated and adaptated into Turkish by Topbaş and Güven (20). Test of Early Language Development, Third Edition (21) consists of two individual subtests, measuring receptive and expressive 
language performances of children between the ages of 2;00 to 7;11 and an overall language score is also provided. Standard scores (with a mean of 100 and a standard deviation of 15) and percentiles are provided for subtest and composite scores.

\section{Stuttering Frequency}

Recordings of children who stutter in spontaneous speech were used for calculating the stuttering frequency. The speech recordings were a minimum of $2 \mathrm{~min}$ in duration and were made in a quiet environment in Eskişehir Research and Training Center for Speech and Language Pathology. An experienced speech therapist collected the speech material and children were suggested to talk about family, friends, favourite films and such like. Percentage of stuttered syllables to total syllables in the speech material were taken to obtain the percent of stuttered syllables.

\section{Statistical Analyses}

Data analysis was conducted using the SPSS 21.00 (22). Shapiro Wilk test was used to verify the normality of the data and independent samples $\mathrm{t}$ test was used to compare the receptive, expressive and composite language test scores between groups. Pearson correlation coefficient was used for the correlation between stuttering severity and language scores. A significance alpha level of $\mathrm{p}<0.05$ was used for all statistical tests.

\section{Results}

A total of 50 children, 14 (\% 28) were girls and 36 (\% 72) were boys between the ages of 3,05 and 7 was included the study. The mean age of the group consisting of CWS was 6.5 $(3,05-7,11)$ with a standard deviation of 1.2 . The 25 CWNS ranged in age from 3,02 to 7,11 (M 6,4) with a standard deviation of 1.1. The CWS and control group have statistically similar age and sex characteristics respectively $(\chi 2=0.347, \quad \mathrm{p}=0.556 ; \chi 2=0.095$ $\mathrm{p}=0.758)($ Table 1).

Table 1.

Demographic profile of CWS and CWNS

\begin{tabular}{lccc} 
& CWS & CWNS & P \\
\hline Gender (girls / boys) & $7 / 18$ & $7 / 18$ & 0.556 \\
Age (SD) & $6 ; 5(1.2)$ & $6 ; 4(1.1)$ & 0.758 \\
Stuttering Severity & $7.5 \%(4.9)$ & - & \\
\hline $\mathrm{p}<0.05$ & &
\end{tabular}

The children's standart scores were computed for each subtest of TELD-3-T. Data was normally distributed on all subtests of TELD-3-T so, a t-test for independent samples is used to compare the language abilities between CWS and the typically developing control group. The scores of TELD-3 Receptive Langauge Subtest, TELD-3 Expressive Langauge Subtest and TELD-3 Composite Scores were lower among CWS than on CWNS group respectively $(M=101.2, S D=1.49)(M=106.4, S D=1.35) ;(M=101.8, S D=1.91)(M=108, S D=1.83) ;(M=102, S D=1.96)$ $(M=106.4, S D=2.96)$.There was a statistically significant difference in the scores on TELD-3-T Expressive Langauge Test between CWS and CWNS; $t(48)=-2.61, p=.012$. CWS had also statistically significantly lower language composite scores than CWNS; $t(48)=-2.34, p=.024$. However, comparison of TELD-3-T receptive language scores for CWS and CWNS revealed no statistically significant differences between the groups $t(48)=-$ 1.54, $p>0.05$. Although CWS scored lower on all subtests of TELD-3-T compared to CWNS, the scores they obtained were all within normal limits as shown in Table 2.

The percentage of speech disfluencies in CWS ranged from $3 \%$ to $24 \%$ with a mean speech disfluency of $7.5 \%$ based on the number of speech disfluencies per 300 syllables of conversation. The types of speech disfluencies included for analysis include, full- and partword repetitions, prolongations, phrase repetitions, blocks and filled pauses. 
Table 2.

Summary of independent t test results on TELD-3-T receptive, expressive and composite scores

\begin{tabular}{llllllll} 
& Group & $N$ & $M$ & $S D$ & $T$ & $D f$ & $P$ \\
\hline TELD-3-T & CWS & 25 & 102.0 & 1.96 & -1.54 & 48 & .129 \\
Receptive Subtest & CWNS & 25 & 106.4 & 2.10 & & & \\
TELD-3-T & CWS & 25 & 101.2 & 1.49 & & & \\
Expressive Subtest & CWNS & 25 & 106.4 & 1.35 & & & .012 \\
TELD-3-T & CWS & 25 & 101.8 & 1.91 & & & \\
Composite Score & CWNS & 25 & 108.0 & 1.83 & & &
\end{tabular}

The correlations between stuttering frequency and TELD-3-T Receptive Test scores $(r(23)=0.29, p=$ $.180)$, TELD-3-T Expressive Test scores $(r(23)=0.26, p=.231)$ and TELD-3-T Composite Scores $(r(23)=0.29, p=.173)$ were low and not statistically significant $(p>0.05)$.

Table 3.

Pearson correlation coefficients for stuttering severity, TELD-3-T receptive, TELD-3-T expressive and TELD-3-T composite scores

CWS TELD-3-T-R TELD-3-T-E TELD-3-T-C

$\begin{array}{llll}\text { Stuttering Severity } & .29 & .26 & .29\end{array}$

\section{Discussion}

The aim of this study was to explore the receptive, expressive and overall language abilities between CWS and CWNS. One of the questions that we set out to address was whether language abilities are relatively more restricted among CWS compared to CWNS, as has been reported in some studies (e.g., 17, 23, 24, 25). Our main findings were that CWS show no receptive language performance differences from their age and gender matched peers while their performance on expressive language subtests and overall language scores were significantly lower compared to CWNS, although still within normal limits. These preliminary results support the hypothesis that CWS show linguistic dissociations or mismatches in receptive versus expressive abilities $(17,24)$ instead of being a mere language disorder as proposed by some researchers $(27,28)$. As argued by Demands and Capacities Model of Stuttering (29), environmental and biological traits impact speech fluency within four areas: motoric, linguistic, emotional, and cognitive. According to this model, when internal (e.g., genetic factors, beliefs about fluency management) or external (e.g., frequency of exposure to fluency-demanding conditions, reponses of peers and teachers) demands exceed a child's capacity, dysfluency is likely to occur. Nippold (30), in her recent review states that CWS, having a compromised motor control system may have difficulty to meet the demand of conveying the intended meaning via fully functional speech system. The findings of relative weakness in expressive language ability of CWS in this study is also concordant with the view that deficits observed in stuttering children result, at least in part, from their atempts to reduce linguistic complexity (31), talking less or using simple and shorter sentence structures as a means of avoidance behavior (32). The findings of limited number of studies carried in Turkish also shows that as mean length of utterances in Turkish increases the frequency of stuttering events also increases $(18,19)$. These findings also support our findings. As mean length of utterance increases the expressive languge complexity also increases. So CWS may avoid talking with foreseeing the 
possibility of stuttering. Lack of correlation between stuttering frequency calculated as percentage of stuttered syllables per 300 syllables and TELD-3-T expressive, receptive and composite scores is consistent with previous studies (33). However, this does not mean that specific aspects of stuttering severity (e.g., duration of stuttering moments) are not associated with language scores in CWS. Unfortunately, this question is out of our study's scope. Future research including such a detailed analysis will help to explore this relationship in a more advanced way. The present findings have important implications from a clinical perspective. Population of CWS is highly heterogenous so that different CWS may exhibit different language profiles and their poor language performance can be associated with stuttering in different ways and to different degrees. So, language assessments should be a part of multidimensional treatment goals and should be tailored according to child's unique needs. This step is indeed crucial for a

\section{References}

1. Arndt, J., \& Healey, E. C. (2001). Concomitant disorders in school-age children who stutter. Language, Speech, and Hearing Services in Schools, 32(2), 68-78.

2. Bernstein Ratner, N. (1997). Stuttering: A psycholinguistic perspective. Nature and treatment of stuttering: New directions, 2, 99127.

3. Wingate, M.E. (2001). SLD is not stuttering. JSLHR, 44 (2), 381-383.

4. Anderson, J. D., \& Conture, E. G. (2001). Language abilities of children who stutter: A preliminary study. Journal of fluency disorders, 25(4), 283-304.

5. Brown, S. F. (1945). The loci of stutterings in the speech sequence. Journal of Speech Disorders, 10(3), 181-192.

6. Bloodstein, O. (2006). Some empirical observations about early stuttering: A possible link to language development. Journal of Communication Disorders, 39(3), 185-191.

7. Silverman, E. M., \& Williams, D. E. (1968). A comparison of stuttering and nonstuttering children in terms of five measures of oral language development. Journal of Communication Disorders, 1(4), 305-309.

8. Watkins, R. V., Yairi, E., \& Ambrose, N. G. (1999). Early Childhood Stuttering IIIInitial Status of Expressive Language Abilities. Journal of Speech, Language, and Hearing Research, 42(5), 1125-1135.

9. Westby, C. E. (1979). Language performance of stuttering and nonstuttering children. comprehensive multidimensional treatment addressing increased fluency as well as other goals. One of the main limitations in this study is the small sample size. Further research with larger samples is needed to replicate and extend the findings reported here. The second limitation is the measuring language ability with only one standardised test. It is important to remember that while standardised tests have lots of advantages, they may not be sufficient to reveal subtle differences in spoken language ability across contexts requiring different social demands. A fully comprehensive assessment of language including standardised language tests, the use of language sampling in multiple contexts (e.g., conversation and narration) can provide more detailed information about expressive language abilities of CWS. Longitudinal data with a wider range of language measures will help to advance our understanding of language profile of CWS at both the theoretical and clinical level.

Journal of Communication Disorders, 12(2), 133-145.

10. Andrews, G., Craig, A., Feyer, A., Hoddinott, S., Howie, P., Neilson, M. (1983). Stuttering: A review of research findings and theories circa. JSLHR, 48 (3), 226-246.

11. Owens, R.E. (2012). Language development: An introduction. 8th Edition. Upper Saddle River, NJ: Pearson.

12. Ratner, N. B., \& Sih, C. C. (1987). Effects of gradual increases in sentence length and complexity on children's dysfluency. Journal of Speech and Hearing Disorders, 52(3), 278287.

13. Bernstein Ratner, N., Sih, C.C. (1987). Effects of gradual increases in sentence length and complexity on children's dysfluency. JSHD, 52 (3), 278-287.

14. Melnick, K. S., \& Conture, E. G. (2000). Relationship of length and grammatical complexity to the systematic and nonsystematic speech errors and stuttering of children who stutter. Journal of Fluency Disorders, 25(1), 21-45.

15. Watkins, R. V., Yairi, E., \& Ambrose, N. G. (1999). Early Childhood Stuttering IIIInitial Status of Expressive Language Abilities. Journal of Speech, Language, and Hearing Research, 42(5), 1125-1135.

16. Häge, A. (2001). Können kognitive und linguistische Fähigkeiten zur Verlaufsprognose kindlichen Stotterns beitragen?. Sprache Stimme- Gehör, 25(01), 20-24. 
17. Watkins, R., Yairi, E., \& Ambrose, N. (2005). Language abilities of young children who stutter. Early childhood stuttering: For clinicians by clinicians, 235-252.

18. Anderson, J. D., Pellowski, M. W., \& Conture, E. G. (2005). Childhood stuttering and dissociations across linguistic domains. Journal of fluency disorders, 30(3), 219-253.

19. Kazanoğlu, D. (2008). Türkçe Konuşan 3-7,5 Yaş Aralığındaki Kekeme Çocukların Kullandıkları Eylemlerin Dilbilimsel Özellikleri İle Akıcısızlık Davranışı Arasındaki İlişkinin İncelenmesi (Master's thesis, Anadolu University, Eskişehir, Turkey).

20. Vatan, M. (2009). Türkçe Konuşan 2.5-9 Yaş Aralığındaki Kekeme Çocukların Kullandıkları İsimler, Sıfatlar, Zarflar, Edatlar, Bağlaçlar ve Zamirlerdeki Takılmalarının Biçim ve Cümledeki Konum Açısından Íncelenmesi (Master's thesis, Anadolu University, Eskişehir, Turkey).

21. Topbaş, S., Topbaş, S., \& Yavaş, M. (2010). Specific language impairment in Turkish: Adapting the TELD-3 as a first step in measuring language impairments. Communication Disorders in Turkish, 137159.

22. Hresko, W. P., Reid, D. K., \& Hammill, D. D. (1999). Test of Early Language Development (TELD). Test of Early Language Development (TELD).

23. IBM_Corp, R. (2010). IBM SPSS statistics for windows. IBM Corp, Armonk, NY. IBM Corp. Released (2012). IBM SPSS Statistics for Windows, Version 21.0. Armonk, NY: IBM Cor.

24. Byrd, K., \& Cooper, E. B. (1989). Expressive and receptive language skills in stuttering children. Journal of Fluency Disorders, 14(2), 121-126.

25. Coulter, C. E., Anderson, J. D., \& Conture, E. G. (2009). Childhood stuttering and dissociations across linguistic domains: A replication and extension. Journal of fluency disorders, 34(4), 257-278.

26. Ryan, B. P. (1992). Articulation, language, rate, and fluency characteristics of stuttering and nonstuttering preschool children. Journal of Speech, Language, and Hearing Research, 35(2), 333-342.

27. Anderson, J. D., Pellowski, M. W., \& Conture, E. G. (2005). Childhood stuttering and dissociations across linguistic domains. Journal of fluency disorders, 30(3), 219-253.

28. Chevekeva, N. (1967). About methods of overcoming stuttering: A survey of the literature. Spetsial Shkola, 3 (1), 9-15.

29. Bloodstein, O. (2002). Early stuttering as a type of language difficulty. Journal of Fluency Disorders, 27(2), 163-167.

Bloodstein, O. (2002). Early stuttering as a type of language difficulty. J Fluency Disord, 27 (1), 163-167.

30. Starkweather, C.W. (2002). The epigenesis of stuttering. J Fluency Disord, 27 (4), 269-288.

31. Nippold, M. A. (2012). Stuttering and language ability in children: Questioning the connection. American Journal of SpeechLanguage Pathology, 21(3), 183-196.

32. Silverman, S., \& Ratner, N. B. (2002). Measuring lexical diversity in children who stutter: Application of vocd. Journal of Fluency Disorders, 27(4), 289-304.

33. Junuzović-Žunić, L., \& Ibrahimagić, A. (2013). Syntactic Skills of Children who Stutter. International Journal of Speech \& Language Pathology and Audiology, 1(1), 29-36

34. Ryan, B. P. (1992). Articulation, language, rate, and fluency characteristics of stuttering and nonstuttering preschool children. Journal of Speech, Language, and Hearing Research, 35(2), 333-342. 